\title{
AZJA POŁUDNIOWO-WSCHODNIA
}

Krzysztof Ziółkowski

\section{CZYNNIKI DECYDUJĄCE O LOKOWANIU BEZPOŚREDNICH INWESTYCJI ZAGRANICZNYCH W KRAJACH STOWARZYSZENIA NARODÓW AZJI POŁUDNIOWO-WSCHODNIEJ (ASEAN)}

\section{Wstęp}

Najkorzystniejszą formą międzynarodowego przepływu kapitału są bezpośrednie inwestycje zagraniczne (BIZ). Wśród wielu ekonomistów dominuje pogląd, że ten rodzaj inwestycji stanowi czynnik przyśpieszający rozwój gospodarczy, szczególnie w grupie krajów rozwijających się. Bezpośrednie inwestycje zagraniczne niewątpliwie są źródłem zewnętrznego kapitału finansowego oraz stanowią efektywny dostęp do nowych technologii, know-how, technik organizacji i zarządzania ${ }^{1}$.

W ostatnich czterdziestu latach proces globalizacji gospodarki światowej przyczynił się do dynamicznego wzrostu bezpośrednich inwestycji zagranicznych głównie w krajach rozwijających się. Zjawisko to wystąpiło również w krajach Azji Południowo-Wschodniej (w krajach $\mathrm{ASEAN}^{2}$ ), które na przełomie lat 80. i 90. rozpoczęły proces transformacji swoich gospodarek i w związku z tym zaczęły się otwierać na napływ kapitału w formie BIZ.

${ }^{1}$ Sabina Młodzianowska, Znaczenie bezpośrednich inwestycji zagranicznych dla rozwoju gospodarczego krajów Ameryki Południowej, Instytut Handlu Zagranicznego, Sopot 2007, s. 4.

${ }^{2}$ W skład Stowarzyszenia Narodów Azji Południowo-Wschodniej (ASEAN) wchodzą: Brunei, Filipiny, Kambodża, Indonezja, Laos, Malezja, Mjanma, Singapur, Tajlandia, Wietnam. 
W artykule zostały poddane analizie czynniki, które napędzają przepływy BIZ do krajów grupy ASEAN; łącznie przeanalizowano sytuację ośmiu krajów tego regionu przy użyciu danych panelowych za lata 1994-20163.

W niniejszym artykule autor postara się zidentyfikować główne czynniki decydujące o napływie bezpośrednich inwestycji zagranicznych. W związku z powyższym postawił dwie tezy: 1. na wielkość bezpośrednich inwestycji zagranicznych w Azji Południowo-Wschodniej wpływa liczba ludności danego kraju; 2. przesłanką napływu BIZ jest stabilność ekonomiczna w omawianym regionie.

\section{Ramy teoretyczne}

Jedną z istotnych cech globalizacji, jaka pojawiła się na początku lat 70. XX w., jest umiędzynarodowienie działalności gospodarczej. Niewątpliwie we współczesnej gospodarce światowej jednym z czynników rozwoju działalności są bezpośrednie inwestycje zagraniczne. Dotyczą one głównie korporacji transnarodowych, które lokują swój kapitał poprzez otwieranie filii w najkorzystniejszych lokalizacyjnie (według inwestorów) rejonach świata.

Teorie bezpośrednich inwestycji zagranicznych usiłują wyjaśnić przyczyny powstawania przedsiębiorstw międzynarodowych i motywy podejmowania działań inwestycyjnych poza terenem kraju oraz określić czynniki wyboru miejsc lokalizacji ich działalności ${ }^{4}$.

W literaturze występuje wiele definicji określających bezpośrednie inwestycje zagraniczne. Andrzej Stępniak uważa, że są to ,[...] lokaty kapitałowe podjęte przez inwestora za granicą w celu uzyskania bezpośredniego wpływu na działalność produkcyjną przedsiębiorstwa, w którym są lokowane lub w celu dostarczenia środków finansowych, dóbr inwestycyjnych, technologii lub know-how przedsiębiorstwu, w którym dana firma posiada udział własnościowy [...]"5.

Natomiast w szerszym znaczeniu bezpośrednie inwestycje zagraniczne oznaczają też filie i oddziały przedsiębiorstw za granicą, jak i udziały w zagranicznych przedsiębiorstwach umożliwiające sprawowanie faktycznej kontroli nad danym

${ }^{3} \mathrm{~W}$ analizie ilościowej pominięto Brunei oraz Mjanmę ze względu na brak kompletnych danych, ale też brak inwestycji bezpośrednich w wymienionych krajach w dłuższym horyzoncie czasowym.

${ }^{4}$ Magdalena Stawicka, Rola bezpośrednich inwestycji zagranicznych $w$ zmniejszaniu dysproporcji rozwojowych nowych krajów członkowskich Unii Europejskiej, http://www.ur.edu.pl/pliki/Zeszyt13/25.pdf, s. 296 [dostęp 2 czerwca 2014].

${ }_{5}$ Andrzej Stępniak, Integracja regionalna i transfer kapitatu. Inwestycje bezpośrednie w aspekcie klimatu inwestycyjnego w Unii Europejskiej, Wydawnictwo Uniwersytetu Gdańskiego, Gdańsk 1996, s. 76. 
podmiotem ${ }^{6}$. Inwestycje bezpośrednie rozumiane w wąskim znaczeniu to zakup przedsiębiorstw już istniejących (inwestycja typu brownfield) lub też budowa nowego przedsiębiorstwa (inwestycja typu greenfield) ${ }^{7}$.

Według OECD bezpośrednie inwestycje zagraniczne można podzielić w następujący sposób ${ }^{8}$ :

- przedsiębiorstwa zależne (subsidiaries), tj. posiadające osobowość prawną, w których inwestor zagraniczny ma ponad 50\% udziałów;

- przedsiębiorstwa stowarzyszone (associated companies), w których inwestor zagraniczny ma mniej niż 50\% udziałów, lecz decydujący wpływ na zarządzanie i podejmowanie decyzji w przedsiębiorstwie;

- oddziały (branches), tj. przedsiębiorstwa, które nie mają osobowości prawnej, założone przez inwestorów na określony czas w celu reprezentowania interesów firmy.

W literaturze przedmiotu przedstawiono wiele teorii związanych $\mathrm{z}$ bezpośrednimi inwestycjami zagranicznymi, choć temat ten występuje dopiero od połowy lat 30. ubiegłego wieku, kiedy to Bertil Ohlin spojrzał na handel jako skutek międzynarodowego podziału produkcji ${ }^{9}$. Jedną z nich jest teoria Marka Cassona, który podzielił bezpośrednie inwestycje zagraniczne na trzy zintegrowane ze sobą grupy, prezentując je w teorii międzynarodowych rynków kapitałowych, teorii przedsiębiorstwa i teorii handlu ${ }^{10}$.

Jedą z mikroekonomicznych koncepcji ujęcia handlu zagranicznego jest teoria lokalizacji bezpośrednich inwestycji zagranicznych, inaczej zwana eklektyczną koncepcją Johna H. Dunninga, która koncentruje się na kwestii rozwoju gospodarczego poprzez kształtowanie pozycji inwestycyjnej na rynkach zagranicznych ${ }^{11}$. Eklektyczna teoria produkcji międzynarodowej wskazuje na trzy główne czynniki decydujące o powstawaniu firm wielonarodowych: własność (od ang. O - ownership), lokalizacja (L - location) i internalizacja (I - internalization). Zdaniem jej twórcy, założenie filii za granicą jest opłacalne wtedy, gdy firma osiąga korzyści z posiadania praw własności względem wiedzy o danym produkcie i procesie jego

${ }^{6}$ Według OECD m.in. 10\% akcji. Patrz: The Detailed Benchmark of Foreign Direct Investment: 3rd Edition, OECD, Paris 1996.

7 Saul Estrin, Klaus E. Meyer, Brownfield Acquisitions: A Reconceptualization and Extension, „Working Paper”, wrzesień 2010, http://klausmeyer.co.uk/publications/WIP_Estrin_Meyer_Brownfield_2009.pdf, s. 3-7 [dostęp 3 czerwca 2014]; Janina Pach, Bezpośrednie inwestycje zagraniczne w świetle bezpieczeństwa ekonomicznego na przykładzie Polski w latach dziewięćdziesiatych XX wieku, Wydawnictwo Naukowe Akademii Pedagogicznej, Kraków 2001, s. 55.

${ }^{8}$ S. Młodzianowska, Znaczenie bezpośrednich..., s. 55.

9 Tamże, s. 19.

${ }^{10}$ Mark C. Casson, Alternatives to the Multinational Enterprises, Longman, London 1979.

${ }_{11}$ John H. Dunning, Explaining the International Direct Investment Position of Countries. Towards a Dynamic or Development Approach, „Weltwirtschaftliches Archiv” 1981, nr 119, s. 3-64. 
wytwarzania. Szczególnie ważne jest, gdy nie jest ona powszechnie dostępna i daje firmie przewagę nad zagranicznymi rywalami mimo konieczności wytwarzania danego dobra w warunkach obcego rynku; lokalizacja filii jest najlepsza z możliwych w perspektywie dłuższego horyzontu czasowego ${ }^{12}$.

Innym spojrzeniem na lokalizację BIZ są teorie, które koncentrowały się wokół problemów rozwoju technicznego. Zgodnie z nimi korzyści komparatywne (czyli względne) poszczególnych krajów zmieniają się w czasie w miarę przechodzenia produktu przez różne fazy. Teoria cyklu życia produktu została stworzona przez Raymonda Vernona, rozwinięta przez Stevena Hirscha oraz Michaela Portera. Podobnie jak teoria luki technologicznej ${ }^{13}$, tak i teoria cyklu życia produktu opiera się na założeniu, że wiedza techniczna nie jest dobrem powszechnym i nie rozprzestrzenia się równomiernie, ponieważ przepływ informacji o sposobie produkcji jest ograniczony na przykład prawem patentowym. Teoria cyklu życia produktu koncentruje się na innowacji konkretnego dobra, inaczej niż w modelu Posnera, który odnosi się do różnych rodzajów innowacji zarówno produktów, jak i procesów wytwórczych. Cykl życia danego dobra obejmuje różne stopnie standaryzacji - od formy zróżnicowanej do formy standardowej - i składa się z czterech faz ${ }^{14}$ : wprowadzenia, wzrostu, nasycenia/dojrzałości, spadku.

Decyzja, w jakiej fazie cyklu życia znajduje się dany produkt, jest podejmowana arbitralnie. Z reguły na konkretną fazę danego wyrobu wskazuje dynamika jego sprzedaży. Niekiedy jako miarę fazy cyklu życia produktu proponuje się zmianę dynamiki sprzedaży w stosunku rocznym ${ }^{15}$.

Biorąc pod uwagę zaprezentowane czynniki, które determinują poszczególne etapy cyklu życia danego dobra, niewątpliwie bezpośrednie inwestycje zagraniczne są jednym ze sposobów przedłużenia życia produktu lub/i wydłużenia poszczególnych cykli. Rozwinięcia powyższej teorii dokonał Kaname Akamatsu ${ }^{16}$, formułując tak zwaną teorię lotu dzikich gęsi. Wskazuje ona, że kraje słabo rozwinięte początkowo importują produkty od krajów wysoko rozwiniętych, a następnie, po uzyskaniu niezbędnej wiedzy technicznej, na przykład wskutek napływu BIZ,

${ }^{12}$ Elżbieta Czarny, Jörn Kleinert, Firmy wielonarodowe w gospodarce światowej, w: tejże (red.), Globalizacja od A do Z, Narodowy Bank Polski, Warszawa 2004, s. 243.

13 Trwała różnica potencjału technicznego i technologicznego dwóch lub więcej gospodarek wynikająca z braku umiejętności stosowania nowych technologii.

${ }^{14}$ Nariman K. Dhalla, Sonia Yuspeh, Forget the Product Life Cycle Concept!, „Harvard Business Review" 1976, t. 54, nr 1, 104; Tim Hindle, Product Life Cycle, w: tenże, Guide to Management Ideas and Gurus, Economist Books, London 2008, s. 153.

15 Philip Kotler, Marketing Management. Analysis, Planning, and Control, Pretice/Hall International Inc., London 1984, s. 355.

${ }^{16}$ Kaname Akamatsu, A Historical Pattern of Economic Growth in Developing Countries, „Journal of Developing Economies" 1962, nr 1, s. 3-11. 
uruchamiają własną, często udoskonaloną produkcję. Według Kiyoshiego Kojimy, autora modelu handlu, istotną cechą bezpośrednich inwestycji zagranicznych jest transfer produkcji z kraju wysoko rozwiniętego do kraju słabiej rozwiniętego. Transfer know-how jest tym łatwiejszy, im mniejsza jest różnica technologiczna między krajem wysoko rozwiniętym a rozwijającym się. Biorąc pod uwagę względne różnice kosztów pracy i kapitału, inwestorzy zagraniczni w krajach słabo rozwiniętych koncentrują się na działalności pracochłonnej, na przykład na przemyśle tekstylnym, wykorzystując lokalną siłę roboczą. Natomiast w krajach wysoko rozwiniętych napływ BIZ dokonuje się przede wszystkim w dziedzinach kapitałochłonnych. W ten sposób we współczesnej gospodarce światowej następuje specjalizacja w skali międzynarodowej, która przynosi korzyści ekonomiczne wszystkim uczestniczącym w niej partnerom handlowym ${ }^{17}$.

\section{Swiatowe trendy inwestycyine}

W porównaniu z rokiem 2015 globalne bezpośrednie inwestycje zagraniczne (BIZ) w 2016 roku spadły o $38 \%$ do 1,75 bln dolarów i jest to najwyższy poziom od czasu kryzysu finansowego z lat 2008-2009. Jednak napływ BIZ wciąż pozostaje o niemal 10\% niższy od szczytu z 2007 r. Fala fuzji transgranicznych i przejęć (M\&A) w roku 2016 wzrosła do 721 mld dolarów w porównaniu z 432 mld dolarów w 2015 r.; ów wzrost stał się głównym czynnikiem globalnego odbicia. Przejęcia te były częściowo napędzane przez reorganizację korporacji transnarodowych (czyli zmiany ich struktury prawnej), w tym inwersji podatkowych ${ }^{18}$.

Patrząc w przyszłość, tendencja przepływu BIZ spadła o 10\% w 2016 r., co świadczy o kruchości światowej gospodarki, uporczywej słabości popytu zagregowanego, braku skutecznych środków politycznych mających na celu zahamowanie oferty inwersji podatkowych oraz spadku zysków przedsiębiorstw wielonarodowych. Podwyższone ryzyko geopolityczne i napięcia regionalne mogą dodatkowo wzmocnić spowolnienienie BIZ w kolejnych latach. Wielkość przepływów BIZ może spadać zarówno w gospodarkach rozwiniętych, jak i rozwijających się. W średnim okresie jednakże przewiduje się wzrost przepływu globalnych BIZ w latach 2017 i $2018^{19}$.

Napływ BIZ do Azji Południowo-Wschodniej wzrósł nieznacznie, o 1\%, do 126 mld dolarów w roku 2016 (w porównaniu z rokiem 2015). Natomiast napływ

17 Sławomir Pastuszka, Zagraniczne inwestycje bezpośrednie $w$ regionie świętokrzyskim $w$ latach 2005-2011, „Gospodarka Narodowa” 2013, nr 10, s. 97.

18 World Investment Report 2016.

19 Tamże. 
BIZ do Singapuru, wiodącego kraju odbiorcy wśród członków ASEAN, odnotował spadek o 5\%, do 65 mld dolarów, a łączna kwota inwestycji typu greenfield zmniejszyła się z 12 mld do 8 mld dolarów w stosunku do roku poprzedniego. Krótkoterminowa niepewność gospodarcza w 2016 r. doprowadziła do spadku napływu BIZ do Indonezji o 29\% w porównaniu z rokiem 2015 i wyniosła 16 mld dolarów. Z kolei napływ BIZ w 2016 r. do Tajlandii wzrósł trzykrotnie, osiągając 11 mld dolarów, choć kwota ta jest wciąż znacznie niższa niż kwoty odnotowane w latach 2012 i $2013^{20}$.

Kraje o niskich dochodach w ASEAN nadal odnotowują wzrost w przepływach BIZ. W szczególności napływ BIZ do Mjanmy (Birmy) wzrósł o prawie 200\%, do około 3 mld dolarów. W sierpniu 2015 r. rządy Mjanmy i Tajlandii podpisały umowę na opracowanie koncepcji specjalnej strefy ekonomicznej w Dawei, w której zostanie zainwestowane łącznie 8,6 mld dolarów (realizacja projektu ma być dwuetapowa).

Napływ BIZ do Wietnamu pozostał w trendzie wzrostowym, głównie dzięki małym i średnim przedsiębiorstwom, które nadal rozwijają swoje zakłady produkcyjne w tym kraju (przede wszystkim przemysł elektroniczny). Największym inwestorem tego regionu jest Samsung, który już produkuje więcej telefonów komórkowych w Wietnamie niż w Chinach.

Jednakże kruchość polityki gospodarczej i niepewność w wielu głównych sektorach gospodarki doprowadziły do ostrożności wśród inwestorów. Ponadto wiele korporacji transnarodowych (KTN) przeprofilowywało swoje inwestycje za granicą, w tym poprzez restrukturyzację swoich aktywów lub ich zbycie czy też przeniesienie $^{21}$.

$\mathrm{Z}$ drugiej strony, pozostaje znaczące ryzyko co do tego optymistycznego scenariusza wzrostu. Takie czynniki jak słabość światowych systemów finansowych, możliwe pogorszenie się otoczenia makroekonomicznego, a także znaczna niepewność polityki gospodarczej w kluczowych obszarach mogą wzbudzać nieufność inwestorów i doprowadzić do dalszego spadku przepływów BIZ ${ }^{22}$.

Rosnące koszty produkcji w Chinach doprowadziły do przeniesienia działalności produkcyjnej przez „obce” KTN, ale też przez chińskie KTN. Zjawisko to zaobserwowano głównie $\mathrm{w}$ obrębie regionu, chociaż są przypadki przeniesienia do innych regionów spoza krajów należących do grupy ASEAN. Tradycyjnie produkcja jest przenoszona do Indonezji i Wietnamu w Azji Południowo-Wschodniej, jak również do Bangladeszu w Azji Południowej.

\footnotetext{
${ }^{20}$ Tamże.

${ }^{21}$ World Investment Report 2013.

22 Tamże.
} 
W ciągu ostatnich kilku lat zagraniczny udział w przemyśle wydobywczym (ropy naftowej, gazu oraz wydobycie metali) pomógł w dodatnim przypływie BIZ w niektórych państwach regionu, na przykład w Mjanmie. W przemyśle naftowym i gazowym poza firmami z Zachodu, które już działają, pojawili się nowi gracze z Indii, Republiki Korei, Tajlandii i Singapuru, którzy prowadzą poszukiwania w Mjanmie.

W przemyśle infrastrukturalnym, szczególnie w takich gałęziach jak transport i telekomunikacja, inwestycje wewnątrzregionalne są szczególnie istotne w Azji Wschodniej i Południowo-Wschodniej. Firmy z siedzibą w Hongkongu (Chiny), Malezji, Singapurze i Tajlandii są głównymi graczami wschodzących gospodarek w tych branżach. W ciągu ostatnich lat w infrastrukturę w Azji Południowo-Wschodniej inwestowały również Chiny. Na przykład China Huadian Corporation, jeden z pięciu największych w kraju wytwórców energii elektrycznej, zainwestował 630 mln dolarów w elektrownię (pierwszy etap) na Bali (Indonezja). W sumie chińskie przedsiębiorstwa zainwestowały dotychczas 7 mld dolarów w rozwój infrastruktury w Indonezji. W transporcie Chiny postanowiły zainwestować kolejne 7 mld dolarów w Laosie (410 km superszybkiej kolei łączącej Kunming i Wientian, która ma zostać uruchomiona w 2018 r.). Natomiast budowa połączenia kolejowego Mjamna-Chiny została już rozpoczęta. Regionalna sieć kolei dużych prędkości łączących Chiny i Singapur ma powstać w najbliższych latach, co znacząco przyczyni się do integracji regionalnej oraz rozwoju gospodarczego w regionie krajów ASEAN.

\section{Analiza empiryczna}

W nawiązaniu do eklektycznej koncepcji Dunninga, artykuł ten koncentruje się głównie na korzyściach wynikających z lokalizacji, które są jedną z trzech kwestii poruszanych w owej teorii. Biorąc pod uwagę paradygmat OLI, autor wyodrębnił czynniki, które mogą wpływać na decyzje lokalizacyjne bezpośrednich inwestycji zagranicznych w Stowarzyszeniu Narodów Azji Południowo-Wschodniej:

$$
(F D I / G D P)_{i t}=c+\beta X_{i t}+u_{i}+v_{t}+\varepsilon_{i t}
$$

Zmienną objaśnianą jest napływ BIZ netto jako procent PKB - to powszechnie stosowany wskaźnik $w$ badaniach empirycznych dotyczących determinant napływu BIZ (zob. rysunek 2). Szczególnie dane dotyczące napływu BIZ, pomiaru ilości inwestycji przez inwestorów niebędących rezydentami z minimum $10 \%$ akcji spółek. Napływ bezpośrednich inwestycji zagranicznych netto to suma nowego 
zainwestowanego kapitału, reinwestowanych zysków i kapitału zainwestowanego między przedsiębiorstwami powiązanymi kapitałowo, wszystko skorygowane o transfery kapitałowe w krajach zagranicznych inwestorów oraz zwrot długu.

Listę zmiennych objaśniających zawiera zmienna X, która oznacza macierz innych czynników mogących przyciągnąć lub zniechęcić do inwestowania w formie BIZ w Stowarzyszeniu Narodów Azji Południowo-Wschodniej. Wektor X składa się z następujących zmiennych. Pierwszą zmienną macierzy jest otwartość handlu. Wpływ otwartości handlu na napływ BIZ zależy od typu BIZ. Gdy kraj otrzymuje BIZ poszukujące nowych rynków zbytu, to znaczy kiedy zagraniczne firmy mają na celu obsługę lokalnego rynku, otwartość handlu może ograniczyć napływ BIZ. Powodem jest teoria skoków taryfowych ${ }^{23}$, zgodnie z którą międzynarodowe firmy starające się obsługiwać lokalne rynki mogą podjąć decyzję o utworzeniu filii w kraju przyjmującym, kiedy trudno jest im eksportować swoje produkty do tego kraju. W przeciwieństwie do międzynarodowych firm, które są zaangażowane w działania zorientowane na eksport swoich produktów za granicę, które wolą angażować kapitał w bardziej otwarte gospodarki, ponieważ protekcjonizm w handlu może zwiększyć koszty transakcyjne, a tym samym zmniejszyć konkurencyjność gospodarki i eksportu. Zatem efekt otwartości handlu na napływ BIZ jest niejednoznaczny. Badania wielu autorów wykazały jednak, że kraje, które są bardziej zaangażowane w handel międzynarodowy, czyli bardziej otwarte, mają więcej bezpośrednich inwestycji zagranicznych ${ }^{24}$.

Jako wskaźnik otwartości handlu przyjęto sumę eksportu i importu jako procent PKB; jest to powszechnie stosowany wskaźnik otwartości handlu w literaturze.

Kolejną zmienną macierzy jest rozwój infrastruktury. Liczne badania podkreślają rolę infrastruktury fizycznej we wzroście i rozwoju gospodarczym ${ }^{25}$. Poza jej bezpośrednim wpływem na wzrost gospodarczy dobra infrastruktura może również wpływać na wzrost gospodarczy poprzez zwiększenie produktywności, ale też

${ }^{23}$ Tariff jumping theory.

${ }^{24}$ Elizabeth Asiedu, On the Determinants of Foreign Direct Investment to Developing Countries. Is Africa Different?, „World Development” 2002, nr 1 (30), s. 107-119; Farhad Noorbakhsh, Alberto Poloni, Ali Youssef, Human Capital and FDI Flows to Developing Countries. New Empirical Evidence, ,World Development” 2001, nr 7 (26); Jacques Morisset, Foreign Direct Investment in Africa: Policies Also Matter, „Transnational Corporations” 2000, nr 2 (9), s. 107-125; Joshua Aizenman, Ilan Noy, FDI and Trade - Two Way Linkages?, „Quarterly Review of Economics and Finance" 2006, nr 3 (46), s. 317-337.

25 World Bank, World Development Report 1994, Oxford University Press, Oxford; Jonathan Temple, The New Growth Evidence, „Journal of Economic Literature” 1999, nr 1 (37), s. 112-156; Sylvie Démurger, Infrastructure Development and Economic Growth. An Explanation for Regional Disparities in China?, „Journal of Comparative Economics” 2001, nr 1 (29), s. 95-117; Chistopher Willoughby, Infrastructure and Pro-Poor Growth. Implications of Recent Research, http://www.dfid. gov.uk/r4d/PDF/Outputs/EngKar/Infrastructure_and_ProPoorGroh.pdf [dostęp 7 czerwca 2014]. 
poprzez pobudzenie nowych inwestycji, zarówno zagranicznych, jak i krajowych. Zdaniem Davida Wheelera i Ashoki Mody'ego ${ }^{26}$ dobra infrastruktura jest ważnym czynnikiem przyciągającym BIZ do krajów rozwijających się. W przekrojowym

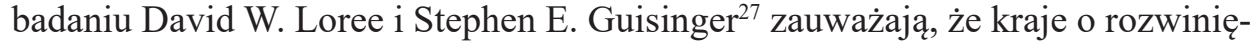
tej infrastrukturze otrzymują więcej BIZ niż kraje o słabszym poziomie rozwoju infrastruktury. Inni autorzy stwierdzili także pozytywny wpływ infrastruktury na napływ bezpośrednich inwestycji zagranicznych ${ }^{28}$.

Jako wskaźnik dostępnej infrastruktury fizycznej przyjęto w pracy logarytm naturalny sumy liczby telefonów komórkowych i linii telefonicznych na 100 mieszkańców, który powinien pozytywnie wpływać na bezpośrednie inwestycje zagraniczne.

Następną badaną zmienną macierzy jest tak zwana stabilność makroekonomiczna. Jest ona powszechnie wymieniana jako jeden z czynników, które zdaniem KTN są brane pod uwagę przy podejmowaniu decyzji inwestycyjnych w krajach rozwijających się. Na przykład Elizabeth $\mathrm{Asiedu}^{29}$ na podstawie wyników badań ankietowych w środowisku biznesowym stwierdziła, że brak stabilności makroekonomicznej jest wymieniany jako jeden z czynników odstraszających napływ BIZ.

Jako miarę stabilności ekonomicznej przyjęto wskaźnik inflacji (CPI). Wysoka inflacja może umacniać niepewność w gospodarce, a także utrudnia podmiotom gospodarczym wyodrębnienie odpowiednich sygnałów z cen względnych ${ }^{30}$. Poprzez tworzenie niepewnej sytuacji gospodarczej wysoki poziom inflacji zmniejsza oczekiwany zwrot z inwestycji. Asiedu ${ }^{31}$ stwierdza, że kraje o wysokiej stopie inflacji w mniejszym stopniu przyciągają BIZ (zob. rysunek 1).

${ }^{26}$ David Wheeler, Ashoka Mody, International Investment Location Decisions. The Case of U.S. Firms, ,Journal of International Economics” 1992, nr 1-2 (33), s. 57-76.

27 David W. Loree, Stephen E. Guisinger, Policy and Non-Policy Determinants of U.S. Equity Foreign Direct Investment, ,Journal of International Business Studies” 1995, nr 2 (26), s. 281-299.

${ }_{28}$ Nagesh Kumar, Infrastructure Availability, Foreign Direct Investment Inflows and Their Export Orientation. A Cross-Country Exploration, http://depot.gdnet.org/cms/conference/papers/3rd_day2_6 nkumar.pdf [dostęp 18 czerwca 2014]; E. Asiedu, On the Determinants..., s. 107-119; Tidiane Kinda, Investment Climate and FDI in Developing Countries. Firm-Level Evidence, „World Development" 2010, nr 38, s. 498-513; H.P. Ngowi, Can Africa Increase Its Global Share of Foreign Direct Investment, „West Africa Review” 2001, nr 2 (2), s. 1-9; Carolyn Jenkins, Lynne Thomas, Foreign Direct Investment in Southern Africa. Determinants, Characteristics and Implications for Economic Growth and Poverty Alleviation, 2002, http://www.csae.ox.ac.uk/reports/pdfs/rep2002-02.pdf [dostęp 17 czerwca 2014].

${ }^{29}$ Edward Asiedu, Foreign Direct Investment in Africa. The Role of Natural Resources, Market Size, Government Policy, Institutions and Political Stability, „World Economy” 2006, nr 1 (29), s. 63-77.

${ }^{30}$ Robert J. Barro, Rational Expectations and the Role of Monetary Policy, „Journal of Monetary Economics” 1976, s. 1-32; tenże, A Capital Market in an Equilibrium Business Cycle Model, „Econometrica” 1980, nr 48 (6), s. 1393-1417.

31 Edward Asiedu, Foreign Direct Investment... 
Jako miarę stopy inflacji przyjęto roczny wzrost wskaźnika cen konsumpcyjnych, skorygowany o efekt obserwacji odstających. Według literatury przedmiotu wpływ stopy inflacji na napływ bezpośrednich inwestycji zagranicznych powinien być negatywnie skorelowany.

Następną zmienną w macierzy jest wielkość rynku krajowego państwa przyjmującego. Kraje o dużym rynku krajowym są w stanie przyciągnąć więcej inwestycji zagranicznych, zwłaszcza tych, które mają na celu obsługę rynku lokalnego. Zatem można się spodziewać, pozytywnego związku między wielkością rynku krajowego a napływem BIZ (zob. rysunek 3).

Wszystkie zmienne objaśniające pochodzą z bazy Banku Światowego (World Development Indicators 2013), Międzynarodowego Funduszu Walutowego (World Economic Outlook) oraz bazy UNCTAD. Dotyczą lat 1994-2012.

Wyniki testu Breuscha-Pagana nakazują odrzucić hipotezę zerową na rzecz alternatywnej, to znaczy pożądane jest wprowadzenie efektów indywidualnych, czyli model panelowy o ustalonych efektach jest właściwszy aniżeli model szacowany za pomocą klasycznej metody najmniejszych kwadratów. Ponadto na podstawie statystyki Hausmana wybrano model z efektami ustalonymi.

Wyniki oszacowanego modelu zostały zaprezentowane w tabeli 1 . W powyższym artykule poddano analizie czynniki, które napędzają przepływy BIZ do Stowarzyszenia Narodów Azji Południowo-Wschodniej, łącznie przeanalizowano siedem krajów tego regionu przy użyciu danych panelowych za lata 1994-2016. Wyniki pokazują, że dwie zmienne znacznie i korzystnie korelują z napływem BIZ. Te zmienne to wielkość rynku ( $\alpha=5 \%)$ oraz infrastruktura $(\alpha=5 \%)$. Warto zauważyć, że zmienna „stabilność ekonomiczna” nie jest statystycznie istotna. Postawiona na wstępie teza badawcza znalazła potwierdzenie $\mathrm{w}$ analizowanym modelu ekonometrycznym. Głównymi zmiennymi wpływającymi na bezpośrednie inwestycje zagraniczne w krajach ASEAN są wielkość tegoż rynku, a także rozwój infrastruktury i otwartość gospodarek.

\section{Zakończenie}

Napływ kapitału do Stowarzyszenia Narodów Azji Południowo-Wschodniej w formie bezpośrednich inwestycji zagranicznych jest głównie skoncentrowany w trzech państwach - Singapurze, Indonezji oraz Wietnamie.

Główną formą inwestycji bezpośrednich w krajach ASEAN są inwestycje typu greenfield. Co prawda we współczesnej gospodarce światowej dominującą formą inwestycji bezpośrednich są fuzje i przejęcia, jednak z perspektywy krajów Stowarzyszenia Narodów Azji Południowo-Wschodniej inwestycje od podstaw są 
korzystniejsze, ponieważ tworzą nowe miejsca pracy, dzięki czemu zwiększają zdolność produkcyjną i powiększają dochód narodowy.

Wśród inwestorów zagranicznych w Azji Południowo-Wschodniej dominują kraje europejskie i Stany Zjednoczone, co świadczy o powiązaniach historycznych pomiędzy kontynentami, ale też o znaczeniu krajów tego regionu w partnerstwie z krajami Unii Europejskiej. Jednocześnie rośnie aktywność inwestycyjna w badanym regionie krajów, które leżą w sąsiedztwie - swoją obecność zaznaczają głównie Korea Południowa, Chiny oraz Japonia. Jest to możliwe na taką skalę, ponieważ równolegle wspomniane państwa notują szybki przyrost rezerw dewizowych. Świadczy to również o rosnących powiązaniach ekonomicznych w regionie Azji i Pacyfiku, co sprzyja pogłębianiu regionalizmu ekonomicznego i uniezależnieniu całego regionu od sytuacji kryzysowych, które występują w gospodarce globalnej ${ }^{32}$. Ważnym czynnikiem determinującym inwestycje wewnątrzregionalne są aspekty kulturowe. W krajach ASEAN znajdują się duże skupiska ludności pochodzącej głównie z Chin, które ułatwiają lokowanie BIZ swoim krajanom ${ }^{33}$.

Kraje Stowarzyszenia Narodów Azji Południowo-Wschodniej powinny zwiększyć działania w celu przyciągnięcia inwestycji do sektora usług i sektora nowych technologii, gdyż sektory te przyczyniają się do rozwoju ekonomicznego krajów słabiej rozwiniętych. Jednak, jak sygnalizuje Bogusława Skulska w swoim artykule, pozycja ASEAN może być zagrożona przez rosnącą dominację Chin i Indii w regionie, co może stwarzać uzależnienie od wspomnianych krajów, zwłaszcza że ich gospodarki są coraz bardziej konkurencyjne w eksporcie. Dlatego też ASEAN musi być aktywnym uczestnikiem ewolucji, tak aby źródłem wzrostu gospodarczego był przemysł zaawansowany technologicznie i aby charakteryzował się dużym poziomem innowacyjności ${ }^{34}$.

W ostatnich dwóch dekadach dzięki inwestycjom BIZ rośnie znaczenie sektora przemysłu przetwórczego w omawianym rejonie. Głównie za sprawą inwestycji ze Stanów Zjednoczonych - możliwość lokalnie montowanych podzespołów z USA i ich reeksport jako gotowych wyrobów do USA (sprzęt biurowy, elektronika).

W krajach Azji Południowo-Wschodniej obserwuje się wzrost zainteresowania nie tylko korporacji transnarodowych, ale też małych i średnich przedsiębiorstw, ponieważ większość krajów z tego rejonu wprowadziła wiele swobód gospodarczych i zachęt do lokowania kapitału w formie BIZ.

32 Bogusława Skulska, Wzrost gospodarczy krajów ASEAN a globalny kryzys, „Studia Ekonomiczne" 2013, nr 2, s. 216-239.

${ }^{33}$ Ewa Oziewicz, Zagraniczne inwestycje bezpośrednie w rozwoju gospodarczym krajów Azji Poludniowo-Wschodniej (ASEAN), Wydawnictwo Uniwersytetu Gdańskiego, Gdańsk 1998.

${ }^{34}$ B. Skulska, Wrost gospodarczy... 
Najważniejszym motywem lokowania BIZ w Stowarzyszeniu Narodów Azji Południowo-Wschodniej jest tania siła robocza oraz wielkość rynku. Motyw ten jest zgodny z tradycyjnym pojmowaniem lokowania BIZ w literaturze, jednak postępujące procesy globalizacji mogą spowodować efekt odwrócenia się inwestorów od tej formy lokowania kapitału.

Kraje Stowarzyszenia Narodów Azji Południowo-Wschodniej, aby pozostać na ścieżce rozwoju gospodarczego, potrzebują nowych inwestycji, w związku z tym muszą tworzyć sprzyjający klimat gospodarczy dla lokowania BIZ oraz wykazywać się stabilizacją gospodarczo-polityczną.

Decyzje o lokowaniu BIZ w Azji Południowo-Wschodniej są podejmowane poprzez pryzmat oceny zarówno poszczególnych krajów tego kontynentu, jak i całego Stowarzyszenia Narodów Azji Południowo-Wschodniej.

Postawiona na wstępie teza badawcza, że na wielkość bezpośrednich inwestycji zagranicznych w Azji Południowo-Wschodniej wpływa liczba ludności danego kraju znalazła swe potwierdzenie w analizowanym modelu ekonometrycznym (zob. tabela 1). Natomiast hipoteza, mówiąca o wpływie stabilności ekonomicznej w omawianym regionie na napływ BIZ nie znalazła odzwierciedlenia w modelu, zatem głównymi zmiennymi wpływającymi na bezpośrednie inwestycje zagraniczne w krajach ASEAN są wielkość tegoż rynku, a także rozwój infrastruktury i otwartość gospodarki.

Rysunek 1. Prognoza BIZ do 2020 r. na tle prognozowanej inflacji

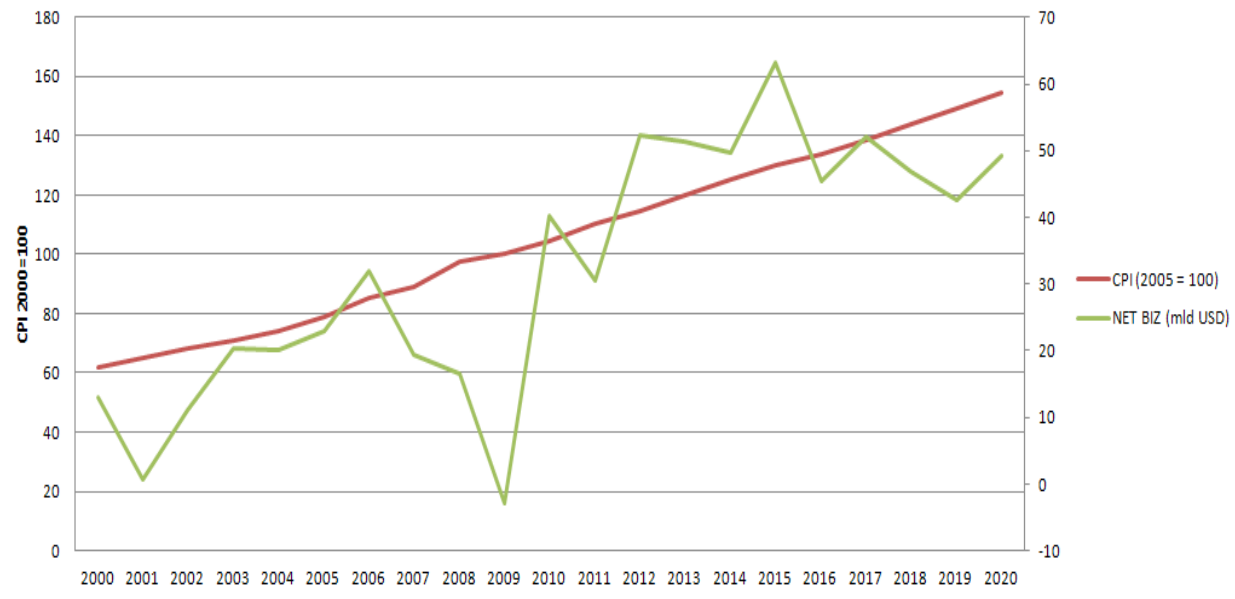

Źródło: Opracowanie własne. 
Rysunek 2. Napływ BIZ (ASEAN) jako \% PKB

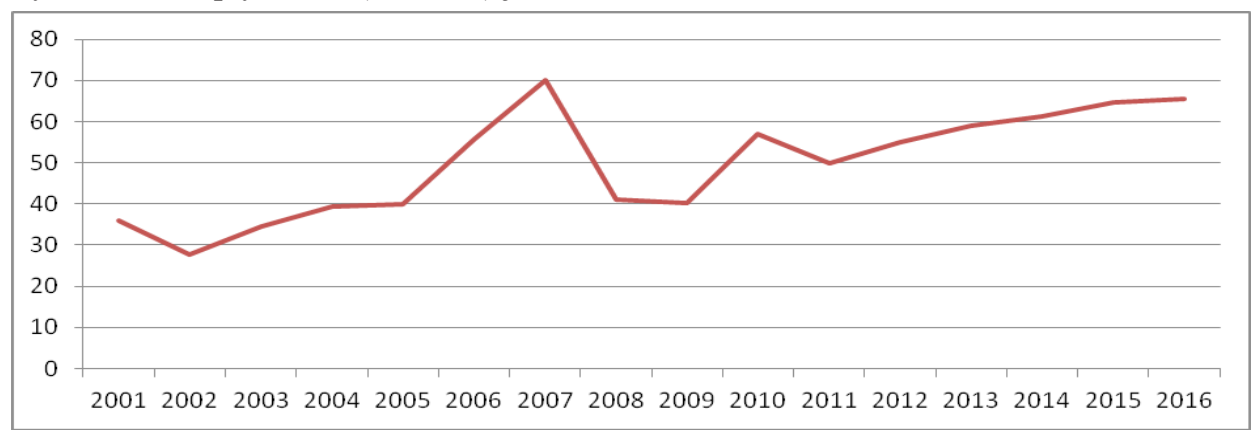

Źródło: Opracowanie własne.

Rysunek 3. Liczba ludności w krajach ASEAN

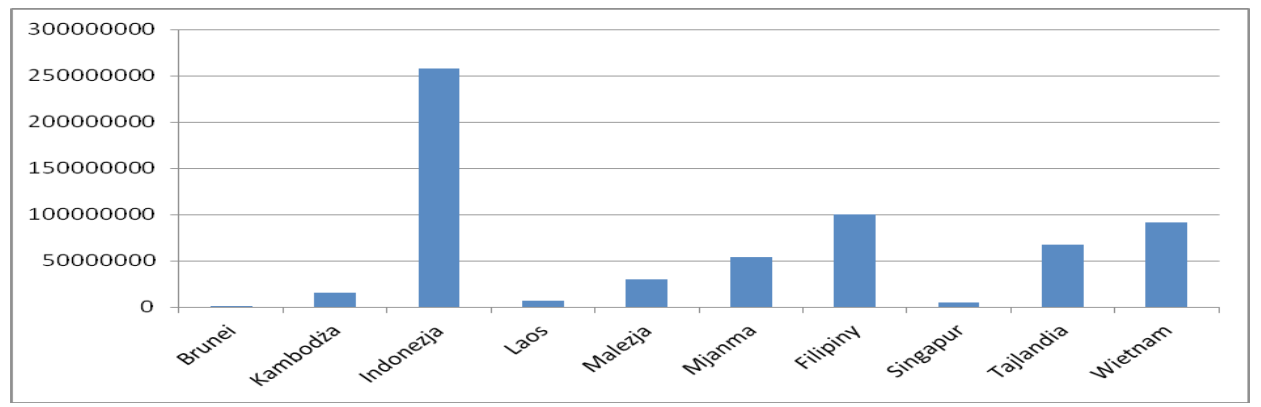

Źródło: Opracowanie własne.

Tabela 1. Czynniki wpływające na napływ BIZ do stowarzyszenia ASEAN

\begin{tabular}{|l|c|l|c|l|}
\hline \multicolumn{1}{|c|}{ Zmienna z macierzy (X) } & Współczynnik & $\begin{array}{c}\text { Błąd } \\
\text { standardowy }\end{array}$ & $\begin{array}{c}\text { Statystyka } \\
\text { t-Studenta }\end{array}$ & \multicolumn{1}{|c|}{ Wartość p } \\
\hline stała & 2,10870 & 0,566137 & 3,725 & $0,0003^{* * *}$ \\
\hline Stabilność ekonomiczna & 0,00221210 & 0,0181028 & 0,1222 & 0,9029 \\
\hline Infrastruktura & $-0,215409$ & 0,102499 & $-2,102$ & $0,0368^{* *}$ \\
\hline Wielkość rynku & 0,0677998 & 0,00611875 & 11,08 & $1,48 \mathrm{e}-022^{* * *}$ \\
\hline Otwartość handlu & 0,0244363 & 0,00971519 & 2,5153 & $0,01302^{* *}$ \\
\hline
\end{tabular}

*** $\alpha=1 \%$;** $\alpha=5 \%$. Poziomy istotności, przy których zmienne objaśniające są statystycznie istotne i wpływają na zmnienną objaśnianą.

Źródło: Opracowanie własne. 
Summary

\section{Determinants of placement foreign direct investments in Associa- tion of South-East Asian Nations (ASEAN)}

In the last forty years, the process of globalization of the world economy has contributed to the rapid growth of foreign direct investment, mainly in developing countries. This phenomenon also occurred in ASEAN (coutries) in the late 80s and the beginning of the 90s of the last century, when the process of transforming their economies began and, therefore, they started to open up to capital inflows in the form of FDI.

In this article I have analyzed factors that drive FDI flows to ASE$\mathrm{AN}$, including the analysis of eight panel countries of the region data for the years 1994-2012.

The author tries to identify main factors determining the inflow of foreign direct investment. The author verifies two thesis: 1) foreign direct investment in Southeast Asia are affected by the population of the region; 2) the second condition for the inflow of FDI is economic stability in the region.

\section{Bibliografia}

1. Aizenman J., Noy I., FDI and Trade - Two Way Linkages?, „Quarterly Review of Economics and Finance" 2006, nr 3 (46).

2. Akamatsu K., A Historical Pattern of Economic Growth in Developing Countries, „Journal of Developing Economies” 1962, nr 1.

3. Asiedu E., Foreign Direct Investment in Africa. The Role of Natural Resources, Market Size, Government Policy, Institutions and Political Stability, „World Economy" 2006, nr 1 (29).

4. Asiedu E., On the Determinants of Foreign Direct Investment to Developing Countries. Is Africa Different?, „World Development” 2002, nr 1 (30).

5. Barro R.J., A Capital Market in an Equilibrium Business Cycle Model, „Econometrica" 1980, nr 48 (6).

6. Barro R.J., Rational Expectations and the Role of Monetary Policy, „Journal of Monetary Economics" 1976.

7. Casson M.C., Alternatives to the Multinational Enterprises, London 1979. 
8. Czarny E., Kleinert J., Firmy wielonarodowe w gospodarce światowej, [w:] E. Czarny, J. Kleinert (red.), Globalizacja od A do Z, Warszawa 2004.

9. Démurger S., Infrastructure Development and Economic Growth. An Explanation for Regional Disparities in China?, „Journal of Comparative Economics" 2001, nr 1 (29).

10. Dhalla N.K., Yuspeh S., Forget the Product Life Cycle Concept!, „Harvard Business Review" 1976, t. 54, nr 1.

11. Dunning J.H., Explaining the International Direct Investment Position of Countries. Towards a Dynamic or Development Approach, „Weltwirtschaftliches Archiv" 1981, nr 119.

12. Estrin S., Meyer K.E., Brownfield Acquisitions: A Reconceptualization and Extension, „Working Paper”, wrzesień 2010, http://klausmeyer.co.uk/publications/WIP_Estrin_Meyer_Brownfield_2009.pdf.

13. Hindle T., Product Life Cycle, [w:] T. Hindle, Guide to Management Ideas and Gurus, London 2008.

14. Jenkins C., Thomas L., Foreign Direct Investment in Southern Africa. Determinants, Characteristics and Implications for Economic Growth and Poverty Alleviation, 2002, http://www.csae.ox.ac.uk/reports/pdfs/rep2002-02.pdf.

15. Kinda T., Investment Climate and FDI in Developing Countries. Firm-Level Evidence, „World Development” 2010, nr 38.

16. Kotler P., Marketing Management. Analysis, Planning, and Control, London 1984.

17. Kumar N., Infrastructure Availability, Foreign Direct Investment Inflows and Their Export Orientation. A Cross-Country Exploration, http://depot.gdnet. org/cms/conference/papers/3rd_day2_6_nkumar.pdf.

18. Loree D.W., Guisinger E.S., Policy and Non-Policy Determinants of U.S. Equity Foreign Direct Investment, ,Journal of International Business Studies” 1995, nr 2 (26).

19. Młodzianowska S., Znaczenie bezpośrednich inwestycji zagranicznych dla rozwoju gospodarczego krajów Ameryki Poludniowej, Sopot 2007.

20. Morisset J., Foreign Direct Investment in Africa: Policies Also Matter, „Transnational Corporations" 2000, $\mathrm{nr} 2$ (9).

21. Ngowi H.P., Can Africa Increase Its Global Share of Foreign Direct Investment, „West Africa Review” 2001, nr 2 (2).

22. Noorbakhsh F., Poloni A., Youssef A., Human Capital and FDI Flows to Developing Countries. New Empirical Evidence, „World Development” 2001, $\mathrm{nr} 7$ (26).

23. Oziewicz E., Zagraniczne inwestycje bezpośrednie w rozwoju gospodarczym krajów Azji Poludniowo-Wschodniej (ASEAN), Gdańsk 1998. 
24. Pach J., Bezpośrednie inwestycje zagraniczne w świetle bezpieczeństwa ekonomicznego na przykładzie Polski w latach dziewięćdziesiatych XX wieku, Kraków 2001.

25. Pastuszka S., Zagraniczne inwestycje bezpośrednie w regionie świętokrzyskim w latach 2005-2011, „Gospodarka Narodowa” 2013, nr 10.

26. Skulska B., Wzrost gospodarczy krajów ASEAN a globalny kryzys, „Studia Ekonomiczne" 2013, nr 2.

27. Stawicka M., Rola bezpośrednich inwestycji zagranicznych $w$ zmniejszaniu dysproporcji rozwojowych nowych krajów członkowskich Unii Europejskiej, http://www.ur.edu.pl/pliki/Zeszyt13/25.pdf.

28. Stępniak A., Integracja regionalna i transfer kapitału. Inwestycje bezpośrednie w aspekcie klimatu inwestycyjnego w Unii Europejskiej, Gdańsk 1996.

29. Temple J., The New Growth Evidence, „Journal of Economic Literature” 1999, nr 1 (37).

30. Wheeler D., Mody A., International Investment Location Decisions. The Case of U.S. Firms, ,Journal of International Economics” 1992, nr 1-2 (33).

31. Willoughby Ch., Infrastructure and Pro-Poor Growth. Implications of Recent Research, http://www.dfid. gov.uk/r4d/PDF/Outputs/EngKar/Infrastructure and_ProPoorGroh.pdf. 